\title{
セメント改良補強土橋台の現地載荷試験 の検証解析
}

\author{
矢崎澄雄 $1 \cdot$ 青木一二三 ${ }^{2} \cdot$ 米澤豊司 ${ }^{3} \cdot$ 篠田昌弘 $4 \cdot$ 舘山 勝 5
}

\begin{abstract}
現地水平載荷試験によるセメント改良補強土橋台の挙動を設計的に再現することを目的として, レベル 2 地震動に対する検討手法である静的非線形解析による逆解析を実施し，本橋台の設計に用 いた補強材ばねなどの設計パラメータの検証を行った．解析は，設計で用いられた解析モデルを基 本として，水平載荷試験の計測結果のひとつである橋台変位をシミュレートすることで行った。 ま た，有限差分法による同様の逆解析を実施し，静的解析により構築した現地橋台の解析モデルを用 いて, 地震時の動的挙動を推定するための動的解析を実施した。本論文は，これら解析結果につい て報告するものである.
\end{abstract}

キーワード：セメント改良補強土橋台，耐震性橋台，限界状態設計法，解析，載荷試験

\section{1.はじめに}

九州新幹線高田トンネルの坑口付近に, 本設構造物と して適用された新しい形式の耐震性橋台であるセメント 改良補強土橋台の，レベル 2 地震動に対する耐震性能を 確認することを主目的として，実橋台の現地水平載荷試 験が実施された 1) ア。

現地水平載荷訊験では，「而震標準 ${ }^{4 」} 」$ に準拠して決 定されたレベル 2 地震動相当の設計水平荷重を橋台に静 的な增分荷重として作用させ, 橋台の変位や部材の応力, 補強材ひずみ, 背面盛土内の土圧等を測定し，耐震性能 の評価・確認を行った.この他，セメント改良アプロー チブロック内に敷設された補強材の引抜け特性を把握す ることを目的として, 実構造物内の試験片による補強材 の引抜き試験も実施されたり"

ここで，本橋台の設計法の基本的な考え方は，耐震標 準による従来型の橋台と同様に，静的非線形解析による 検討を主体としている．従来橋台の設計との大きな違い は基礎の地艋ばね和加えて，本橋台の設計では補強材の 引張ばねを静的非線形解析に考慮した点である.

セメント改良補強土橋台の安定に対する抵抗要素を想 定した場合，従来の直接基礎形式の橋台が基礎の地盤ば ねに安定を依存しているのに対して，本橋台の場合には， 基礎の地盤には鉛直支持のみを期待し，水平力に対する 抵抗は地盤抵抗よりも補強材ばねに依存させる構造形式 となっている.このため, 設計段階における補強材のば ね定数の設定が, 直接設計結果の変形性能として現れる.

したがって，補強材のばね定数の設定が本橋台の設計 では最も重要な項目のひとつである.しかし，セメント
改良アプローチブロック内での補強材の引張り特性は, これまで十分に把握されていなかったことから，今回実 施した各現地試験結果を，解析的に検証することで，設 計一反映させることが重要となる.

そこで，現地水平載荷試験によるセメント改良補強土 橋台の挙動を, 静的非線形解析による逆解析を行うこと で設計的に再現し，本橋台の設計に用いた解析モデルや 補強材ばねなどの設計パラメータの検証を行うこととし た. また，有限差分法による同様の逆解析を静的解析に より実施することで, 有限差分法に用いる現実的な解析 モデルを構築し，このモデルを用いてレベル 2 地震動に よる動的解析を行い，本橋台のレベル 2 地震動に対する 動的挙動を推定することとした.

\section{2. 現地水平載荷試験による橋台の変形モ一ド}

逆解析は, 現地水平載荷試験の水平変位をシミュレー トすることで行う．したがって, 載荷試験での橋台の変 形状況を分析したうえで解析を行う必要がある. 水平載 荷による橋台の変形は，(1)橋台躯体の変形，(2)土襄部分 の補強材伸張による変形, (3)セメント改良補強アプロー チブロック自体の伸張変形, および(4)橋台躯体とアプロ 一チブロックが一体となっての転倒変形が合わさっての 変形であると，各計測結果から想定された. 上記(1)〜(4) 全てによるセメント改良補強土橋台としての変形（以降, 全体変形と称す) は, 最大載荷荷重 $(4000 \mathrm{kN})$ 時の計測 結果から図ー1に示寸ようにパラペット上端で $15.5 \mathrm{~mm}$,

1 正会員，株式会社複合技術研究所，技術部（テ107-0052 港区赤坂2-15-16 赤坂ふく源ビル7F） 23正会員，独立行政法人 鉄道建設・運輸施設整備支援機構 鉄道建設本部設計技術室 基礎土構造（テ231-8315 神奈川県横兵市中区本町6-50-1 横浜アイラ ンドタワー） 4,5正会員，財団法人鉄道総合技術研究所，基礎土構造（广185-8540 国分寺市光町2-8-38） 
フーチング上面部で-1. $8 \mathrm{~mm}$ であり，セメント改良アプロ 一チブロックと一体になって転倒変形し，背面盛土上面 にはクラックが観測されている．また，相対変位計によ る計測結果より，(2)の土囊部分の補強材伸張による変位 は, 図ー2に示すように析座面の高さで $2.3 \mathrm{~mm}$, フーチン グ下面から $5 \mathrm{~m}$ の位置で $0.2 \mathrm{~mm}$ であった。

静的非線形解析による設計は，変形モード(2)の土囊部 分の補強材伸張による変位に対するものであり, (1)〜 (4) の全体変形モードの逆解析は静的非線形解析では実施で きない.このことから, 全体変形に対する逆解析を有限 差分法により実施することとした。

\section{3. 静的非線形解析による逆解析}

耐震標淮に示される鉄道橋台の地震時設計手法である 静的非線形解析により，セメント改良補強土橋台の現地 水平載荷試験の逆解析を実施し，本橋台の設計に用いた 補強材ばね定数や背面地盤のばね定数の妥当性を検証し た.

\section{（1）解析条件}

逆解析に用いた解析モデルは現地橋台の設計で用いら れた解析モデルを基本として，解析は，補強材ばね定数 およひ橋台背面の地盤ばね定数をパラメータとして，水 平載荷試験による水平変位をシミュレートすることによ り行った.

\section{a) 解析モデル}

解析モデルを図一 3 に示す. 節点 6 が水平載荷位置 であり，節点荷重で水平方向増分荷重として $4000 \mathrm{kN} /$ 全 幅を 400 ステップで与え, 節点 5 には桁反力としての鉛 直荷重 $1350 \mathrm{kN}$ 全幅を増分しない荷重として与え, 各要

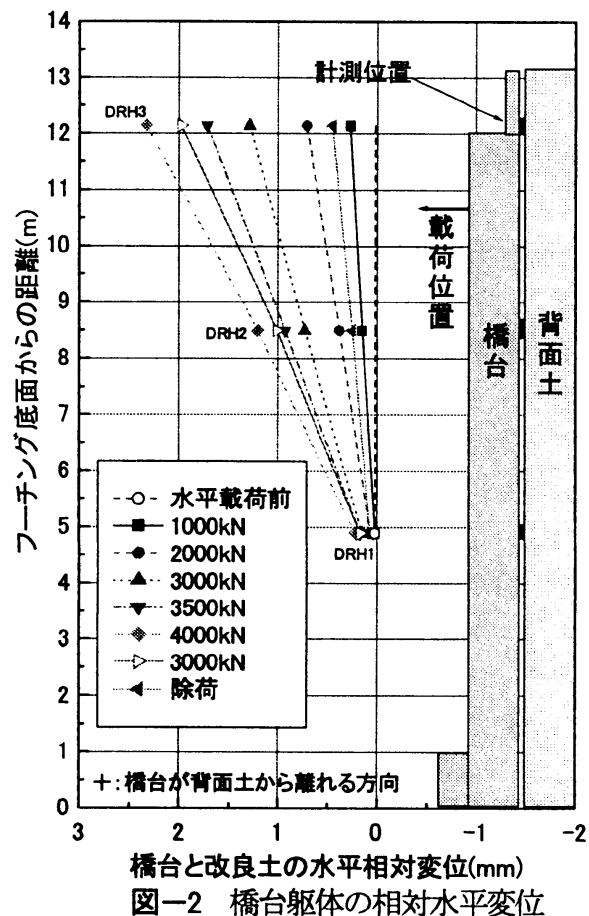

素には橋台自重を要素軸方向分布荷重（増分しない荷 重）として与えた．補強材ばねは節点水平ばねとして， 図一3に示す各節点の受け持つ本数分を与えた．また, 地盤ばねとしては，背面地盤ばねを節点 1 1 18 に水平方 向ばねとして与え，フーチング下面の鉛直・回転ばねを 節点 18 に考慮した。

なお，解析は橋台全幅 (11.3m) で実施した.

b) 橋台部材の非線形特性

表一1 に橋台部材の諸元を示す. パラペット（胸壁） および躯体は鉄筋コンクリート非線形部材として与え, フーチングは剛体として考慮した.

c）解析パラメータの設定

本解析では，補強材ばね定数，背面地盤のばね定数を パラメータとして, 橋台の水平変位をシミュレートする こととした.
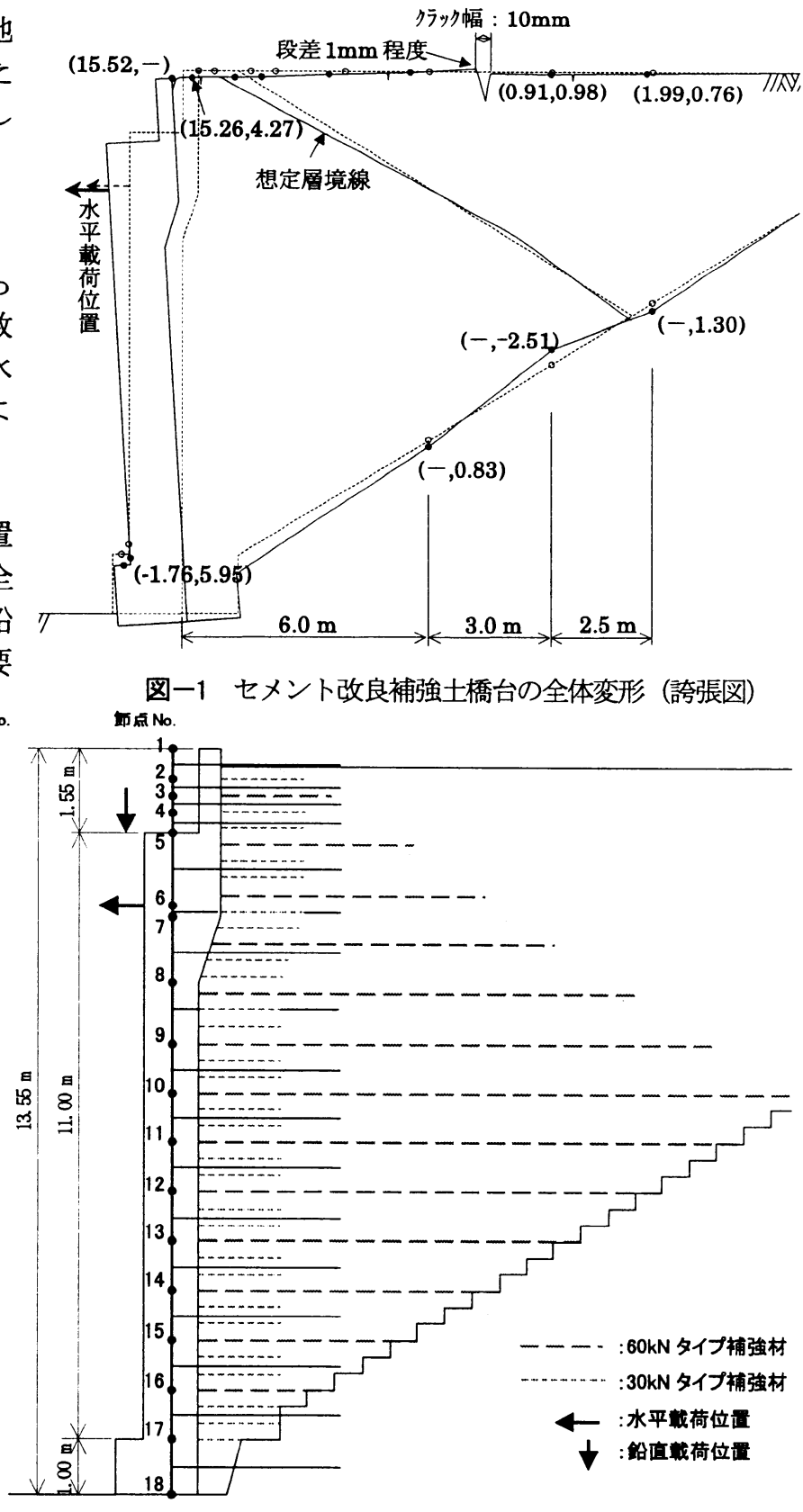

図一3 静的非線形解析モデル 
表-1 橋台部材の諸元

\begin{tabular}{|c|c|c|c|c|c|c|c|c|}
\hline \multirow[b]{2}{*}{ 種別 } & \multirow[b]{2}{*}{$\begin{array}{l}\text { 適用 } \\
\text { 要素 } \\
\text { 番号 }\end{array}$} & \multirow[b]{2}{*}{$\begin{array}{c}\text { 断面 } \\
\text { 高さ } \\
(\mathrm{mm})\end{array}$} & \multicolumn{3}{|c|}{ 断面の諸元 } & \multicolumn{3}{|c|}{ せん断補強鉄筋 } \\
\hline & & & $\begin{array}{c}\text { 被り } \\
(\mathrm{mm})\end{array}$ & $\begin{array}{l}\text { 径 } \\
(\mathrm{mm})\end{array}$ & $\begin{array}{l}\text { 本数 } \\
\text { (本) }\end{array}$ & $\begin{array}{l}\text { 径 } \\
(\mathrm{mm})\end{array}$ & $\begin{array}{l}\text { 本数 } \\
\text { (本) }\end{array}$ & $\begin{array}{c}\text { 配置 } \\
\text { 間隔 } \\
(\mathrm{mm})\end{array}$ \\
\hline 胸壁 & (1) (4) & 400 & $\begin{array}{l}80 \\
80\end{array}$ & $\begin{array}{l}19 \\
19\end{array}$ & $\begin{array}{l}58 \\
58\end{array}$ & 16 & 28 & 200 \\
\hline \multirow{3}{*}{ 躯体 } & (5), (6) & 1400 & $\begin{array}{l}80 \\
80 \\
\end{array}$ & $\begin{array}{l}25 \\
19 \\
\end{array}$ & $\begin{array}{l}58 \\
58 \\
\end{array}$ & 16 & 18 & 200 \\
\hline & (7) & 1200 & $\begin{array}{l}80 \\
80 \\
\end{array}$ & $\begin{array}{l}25 \\
19 \\
\end{array}$ & $\begin{array}{l}58 \\
58 \\
\end{array}$ & 16 & 18 & 200 \\
\hline & (8) (16) & 1000 & $\begin{array}{l}80 \\
80\end{array}$ & $\begin{array}{l}25 \\
19\end{array}$ & $\begin{array}{l}58 \\
58\end{array}$ & 16 & 18 & 200 \\
\hline 7 7チグ & (17)制域 & 1500 & - & - & - & - & - & - \\
\hline
\end{tabular}

表一2 各節点の補強材ばねの入力值

\begin{tabular}{|c|c|c|c|c|c|c|c|c|}
\hline \multirow{2}{*}{$\begin{array}{l}\text { 節点 } \\
\text { Noo. }\end{array}$} & \multicolumn{2}{|c|}{$\begin{array}{l}\text { 節点が受け持つ } \\
\text { 補強材本数 (本) }\end{array}$} & \multirow{2}{*}{$\begin{array}{l}\text { 換算 } \\
\text { 本数 } \\
\text { (本) }\end{array}$} & \multicolumn{3}{|c|}{$\begin{array}{c}\text { 補強材ばね定数 } \\
(\mathrm{kN} / \mathrm{m} / \text { 全幅 }) \\
\end{array}$} & \multicolumn{2}{|c|}{$\begin{array}{c}\begin{array}{c}\text { 制限値 } \\
(\mathrm{kN} / \text { 全幅) }\end{array} \\
\end{array}$} \\
\hline & $\begin{array}{l}30 \mathrm{kN} \\
\text { 伊 }\end{array}$ & $\begin{array}{l}60 \mathrm{kN} \\
\text { 伊 }\end{array}$ & & ケ-X 1 & $r-x 2$ & $r-x_{n}$ & 引張側 & 圧縮側 \\
\hline 1 & 0 & 0 & 0 & - & - & - & - & - \\
\hline 2 & 1 & 0 & 1 & 1000 & 2000 & $1 \cdot X$ & 339 & 0 \\
\hline 3 & 0 & 1 & 2 & 2000 & 4000 & $2 \cdot x$ & 678 & 0 \\
\hline 4 & 1 & 0 & 1 & 1000 & 2000 & $1 \cdot X$ & 339 & 0 \\
\hline 5 & 2 & 1 & 4 & 4000 & 8000 & $4 \cdot X$ & 1356 & 0 \\
\hline 6 & 1.5 & 1 & 3.5 & 3500 & 7000 & $3.5 \cdot X$ & 1186.5 & 0 \\
\hline 7 & 1.5 & 1 & 3.5 & 3500 & 7000 & $3.5 \cdot X$ & 1186.5 & 0 \\
\hline 8 & 2.5 & 1 & 4.5 & 4500 & 9000 & $4.5 \cdot X$ & 1525.5 & 0 \\
\hline 9 & 2.5 & 1 & 4.5 & 4500 & 9000 & $4.5 \cdot X$ & 1525.5 & 0 \\
\hline 10 & 2 & 1 & 4 & 4000 & 8000 & $4 \cdot X$ & 1356 & 0 \\
\hline 11 & 2 & 1 & 4 & 4000 & 8000 & $4 \cdot X$ & 1356 & 0 \\
\hline 12 & 2 & 1 & 4 & 4000 & 8000 & $4 \cdot X$ & 1356 & 0 \\
\hline 13 & 2 & 1 & 4 & 4000 & 8000 & $4 \cdot X$ & 1356 & 0 \\
\hline 14 & 2 & 1 & 4 & 4000 & 8000 & $4 \cdot X$ & 1356 & 0 \\
\hline 15 & 2 & 1 & 4 & 4000 & 8000 & $4 \cdot X$ & 1356 & 0 \\
\hline 16 & 2 & 1 & 4 & 4000 & 8000 & $4 \cdot X$ & 1356 & 0 \\
\hline 17 & 2 & 0 & 2 & 2000 & 4000 & $2 \cdot X$ & 678 & 0 \\
\hline 18 & 0 & 0 & 0 & - & - & - & - & - \\
\hline
\end{tabular}

\section{(1)補強材ばね定数の設定}

補強材ばね定数は, 本解析では $30 \mathrm{kN}$ タイプの補強材 1 本を基準として，60kN タイプの補強材ばねは $30 \mathrm{kN}$ タイ プの 2 倍の值であるとして, 各節点が負担する $30 \mathrm{kN}$ タイ プの本数に換算することとした. 表一2に, 各節点が負 担する補強材の各タイプの本数および $30 \mathrm{kN}$ タイプの補 強材に換算した本数を示す. 解析は, 表中に示すように 換算本数に X 倍した值を用いてトライアル計算を実施し た. また, 補強材ばねはバイリニアとしてモデル化して おり, その上限值は補強材の設計引張強度とした。

\section{(2)背面地盤のばね定数}

セメント改良アプローチブロックからなる背面地盤の ばね定数は, トライアル計算を行うことにより着目する 変位がシミュレートできる值を求めた.

なお，直接基礎の鉛直地盤ばね定数，地盤のばね定数

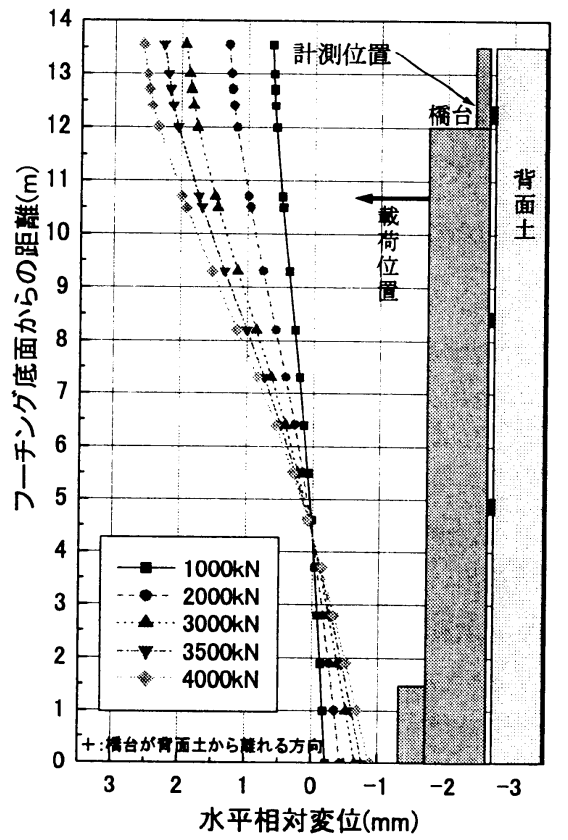

図一4 解析結果による水平変位分布

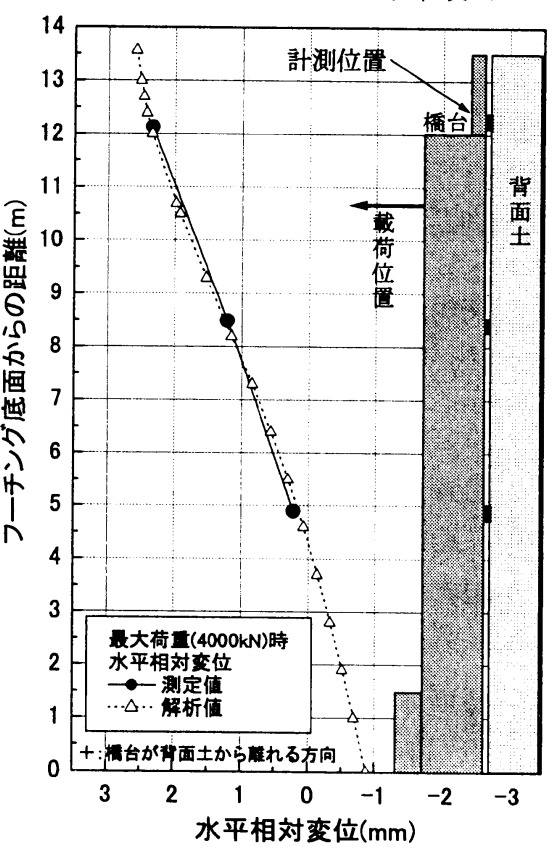

图一5 水平変位分布の比較

表-3 水平変位量分布の比較

\begin{tabular}{c|c}
\hline パラメータ & ばね定数 $(\mathrm{kN} / \mathrm{m} /$ 全幅 $)$ \\
\hline $\begin{array}{c}\text { 補強材ばね定数 } \\
\text { (表一2の }\end{array}$ & $80000 \times($ 值 $)$
\end{tabular}

についてはバイリニアによるモデル化をしており，設計 計算書による值を用いた。

\section{（2）解析結果}

トライアル計算により, 橋台の相対変位にほぼ一致し たときの解析結果による橋台水平変位の分布を，図一 4 に荷重段階ごとに, 図一 5 に最大水平荷重 $(4000 \mathrm{kN})$ 時の 
測定結果と解析結果の水平変位分布の比較を示す．また, このときの各パラメータの值を表一3に示す.

図一 5 から, 最大荷重時の水平変位の分布はほぼ一致 していることがわかる. 次に図一2および図ー4から， パラペット上端位置での荷重〜変位関係として整理した 結果を図一6に示す．解析では各ばね定数をバイリニア としてモデル化しているため, 上限値に達しない限りば ね定数は一定であることから, 線形的な荷重〜変位関係 となっていることがわかる.これに対して，水平載荷試 験の荷重〜変位関係は非線形であり, 荷重レベルが増加 するに従い勾配が緩くなる傾向にあることがわかる. こ のことは，実際の構造物内の補強材ばね定数が非線形で, 荷重レベルすなわち補強材に作用する引張力が大きくな るほど低下していることを示している。

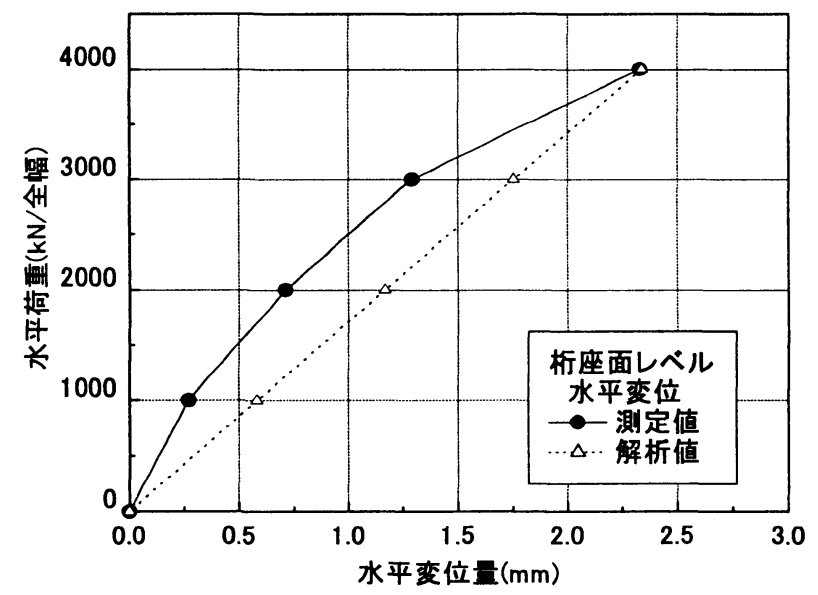

図一6 荷重〜変位関係の比較

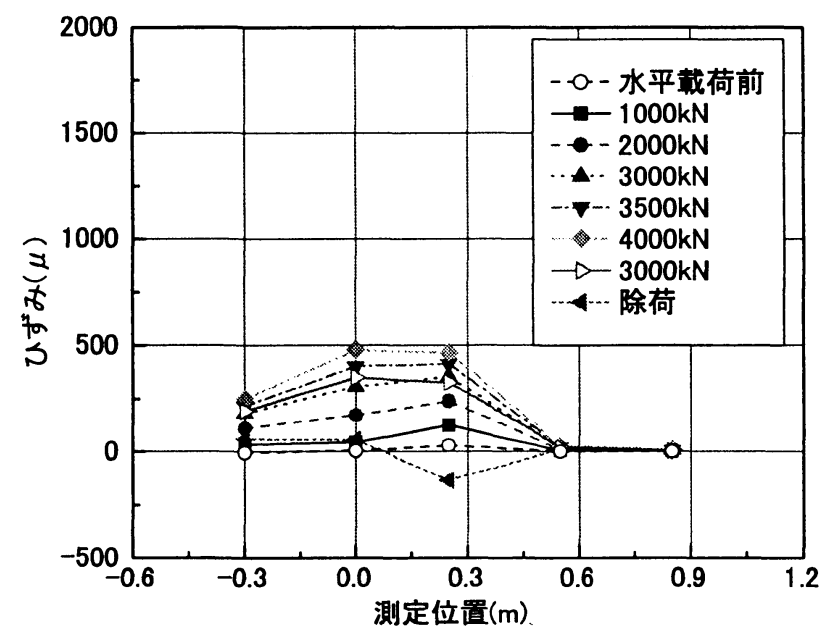

図一7 補強材ひずみ測定值分布の一例

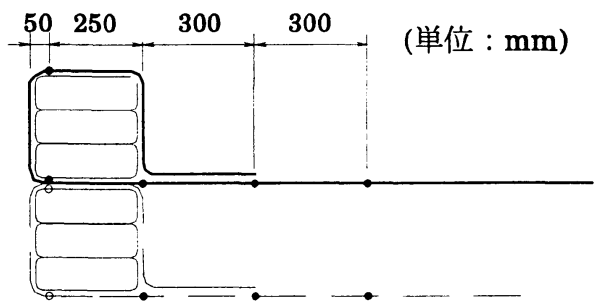

図ー8 ひずみゲージ貼付け位置

\section{（3）逆解析結果による補強材ばね定数の考察}

表ー3 に示した逆解析により求められた補強材のばね 定数について，実際の構造物の設計に用いた補強材ばね 定数の結果から得られるばね定数との比較を行い，今後, 静的非線形解析の設計に考慮すべき補強材ばね定数につ いて検討を行う。なお，現地で実施した補強材引抜き試 験結果 ${ }^{5}$ からの考察は(4)に述べる。

解析においては, $30 \mathrm{kN}$ タイプの補強材を基本として考 えたことから，以下に実際の設計で設定した $30 \mathrm{kN}$ タイ プの補強材の設計ばね定数の算定を示す。

設計では，気中での引張り試験により，補強材の伸び が5\%のときの荷重〜伸びひずみの関係を用いて，伸びし ろ $1.5 \mathrm{~m}$ 当たりのばね定数を公称ばね定数 $\mathrm{k}_{\mathrm{gt}, 0}$ としている.

実設計においては，この $\mathrm{k}_{\mathrm{8to}}$ を基本として，地中での ばね定数に対する補正係数, 土襄部分の折返しによる効 果, セメント改良アプローチブロック内での補強材伸び しろ長を考慮して，以下のように解析に用いる補強材の ばね定数を設定した.

$\mathrm{k}_{\mathrm{gt}}=$ (気中 $5 \%$ 伸び，伸びしろ $1.5 \mathrm{~m}$ での $\mathrm{k}_{\mathrm{gt}}$ 。 $\times$

（従来の実験等による補正係数） $\times$ (折返し効果)

$=\mathrm{k}_{\mathrm{gt}, 0} \times 5 \times 2=10 \cdot \mathrm{k}_{\mathrm{gt}, 0}(\mathrm{kN} / \mathrm{m} / \mathrm{m})$

ここで，セメント改良土内での補強材の伸びしろを $40 \mathrm{~cm}$ と仮定し, さらに橋台全幅でのばね定数を以下のよ うに求めた.

$\mathrm{k}_{\mathrm{gt}}=10 \cdot \mathrm{k}_{\mathrm{gto}} \times(150 / 40) \times 11.3$

$=424 \cdot \mathrm{k}_{\mathrm{gto}}=424 \times 200=84800(\mathrm{kN} / \mathrm{m} /$ 全幅 $)$

したがって，実際のセメント改良補強土橋台の設計に 用いたばね定数は，逆解析結果とほぼ一致している.

ここで，水平載荷試験時に計測した補強材ひずみの分 布図の一例を図一7に示す. 補強材のひずみは図一8に 示す位置にひずみゲージを貼り付けて計測したものであ る. 図ー7から, 引張りひずみが発生している領域は, 橋台背面から $30 \mathrm{~cm}$ の位置の測定点までであり, $55 \mathrm{~cm}$ の 位置ではひずみが発生しておらず，このことから，伸び しろを土襄部分の幅 $40 \mathrm{~cm}$ として設計ばね定数を求めた ことは，比較的現実的であったものと考えられる．また， 折り返し部分の測定点（図一 7 の $-0.3 \mathrm{~m}$ の点）について も引張りひずみが発生しており，このことから，折り返 し効果もあることが確認された。

以上より，設計で用いた補強材ばね定数の設定方法が 比較的現実的であると判断することができる.

\section{(4) 補強材引抜き試験結果と補強材設計ばね定数の関係}

(3)より，橋台の安定に対する静的非線形解析に用い る補強材のばね定数については, 設計値と逆解析により 求めた值とがほぼ一致する結果となった。ここでは, 現 地水平載荷試験の際に実物の補強アプローチブロックを 用いて行った補強材引抜き試験の結果から，補強材先端 位置でのばね定数を求め, 設計で用いたばね定数との比 較を行う。

引抜き試験は, $30 \mathrm{kN} / \mathrm{m}$ タイプの製品および $60 \mathrm{kN} / \mathrm{m}$ タイ プの製品の 2 種類について, フーチング下面を第 1 層の 
補強材として, フーチング下面から 16 層目および 30 層 目の計 4 ケースを実施した.

図一 9 に, 各ケースの荷重〜引抜き変位関係を示す. 各図から, 履歴を受けた荷重程度までの変位の発生量が 大きく，履歴を受けていない荷重からの変位が小さい発 生傾向にあり, その結果ヒステリシスループとなってい ることがわかる.これは, 荷重の増加と共に補強材と地 盤との摩擦切れが進行的に奥に進むためと考えられる.

補強材のばね定数は，図一9の各荷重〜変位ループの 割線での傾きとして, 各荷重段階ごとに整理を行うこと とした. その際, 引抜き試験は, 幅 $13.8 \mathrm{~cm}$ (7 자ラド ) の試験片で実施しており，ひずみゲージの貼付けのため, 中央 2 本のストランドは地盤と摩擦が取れていなかった 可能性があったため, 橋台全幅でのばね定数の換算は, これらを考慮して行った.

図一 10 および図－11に，各製品の橋台全幅に換算 した補強材ばね定数を引抜き荷重レベルごとに示す.同 図から，補強材ばね定数は，荷重レベルが大きくなるに 従い減少し，一定值に収束する傾向にあることがわかる. これは，前述のヒステリシスループのためである. 同図 には，設計で用いた補強材ばね定数を示したが，設計ば ね定数は荷重レベルの低いばね定数に近いことがわかる. レベル 2 地震動の設計で用いる補強材のばね定数とし ては，補強材は地震が発生して初めて大きな引張力を受 けると考えることができることから，図一 10 ，図一 1 1の荷重レベルの低いばね定数を適用してよいものと考 えられ，設計で用いている補強材ばね定数は比較的妥当 性の高い值であると判断できる.

\section{（5）橋台背面地盤のばね定数に関する考察}

橋台背面地盤のばね定数は，実際には土囊によるばね であると考えられる．表一3に示した逆解析により求め られた背面地盤のばね定数は $65000 \mathrm{kN} / \mathrm{m}$ であり, 節点間 隔が約 $1.0 \mathrm{~m}$ であるので，奥行き $1.0 \mathrm{~m}$ 当たりの設計水平 地盤反力係数は $\mathrm{k}_{\mathrm{h}}=65000 \mathrm{kN} / \mathrm{m}^{3}$ となる. したがって, 逆解 析の結果から単純に土囊部分を地盤として評価した場合, $\mathrm{N}=20$ 程度の砂層と想定できる.

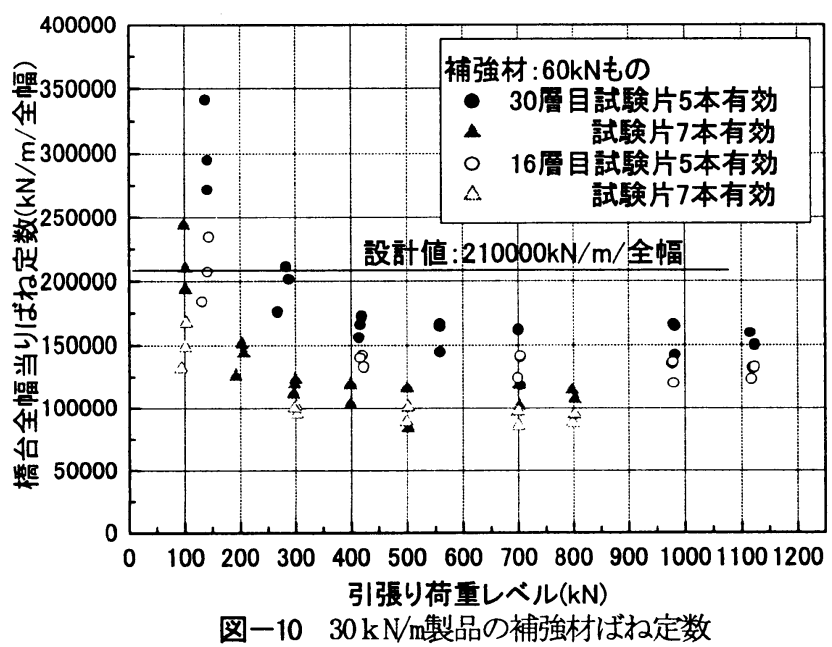

\section{4. 有限差分法による逆解析}

現地水平載荷試験によるセメント改良補強土橋台の全 体変形をシミュレートし, 解析モデルの各物性等, 現実
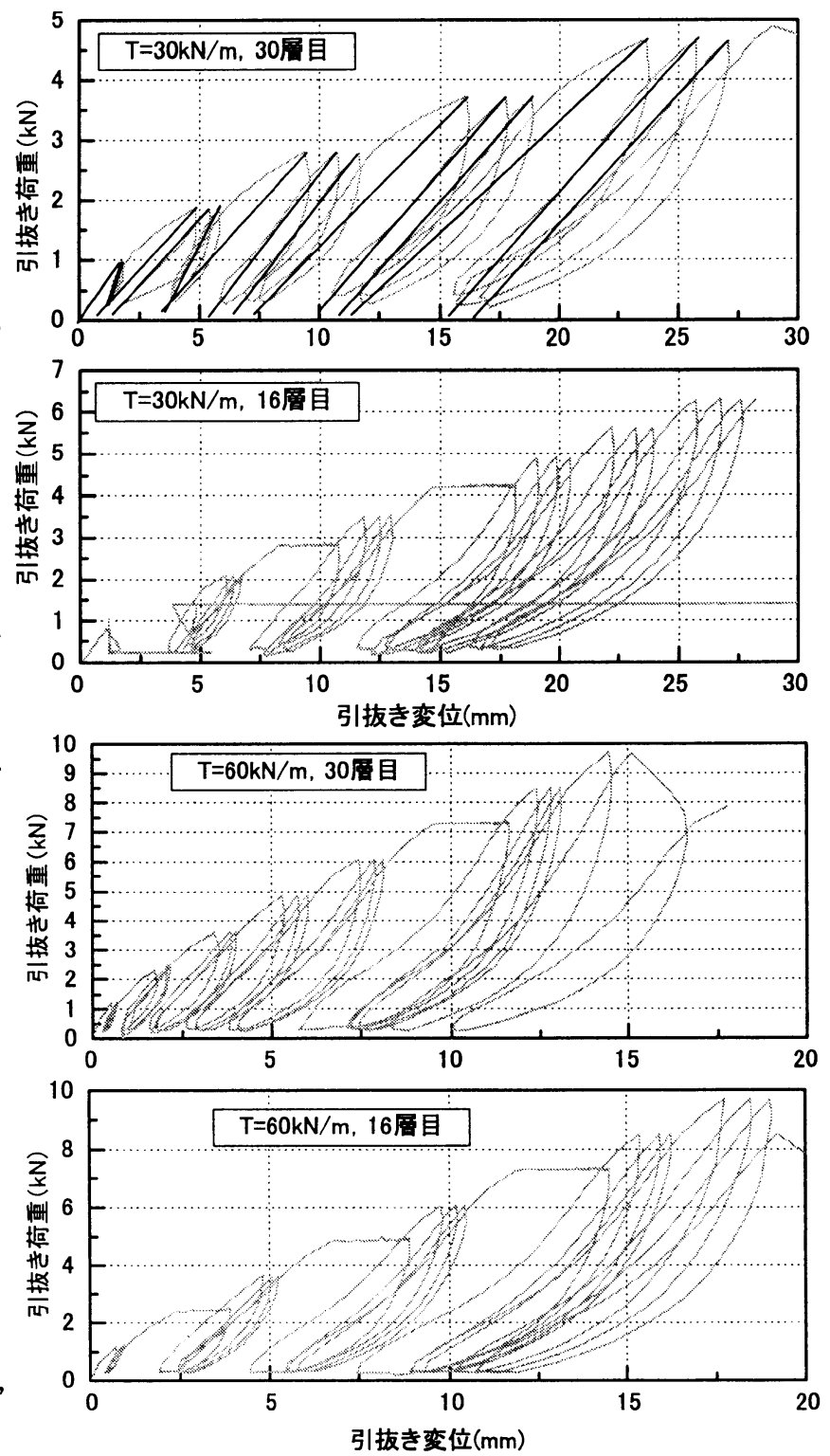

図一9補強材引抜き試験の荷重〜変位関係

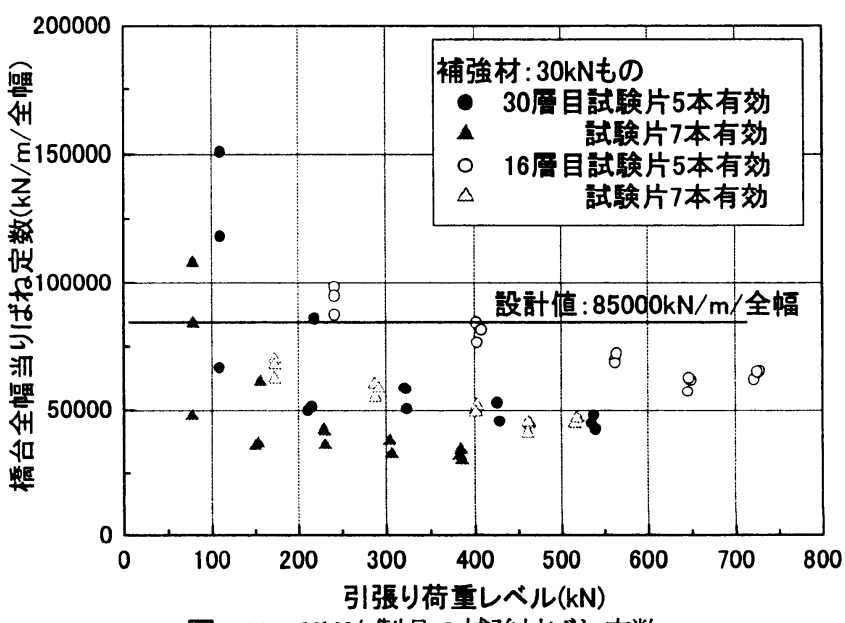

図ー11 60kN/m製品の補強材ばね定数 
的な解析モデルを構筑することを目的として，有限 差分法による解析を実施した.

ここで, 有限差分法は，解析対象を有限の格子に 離散化し，各格子において差分計算式により直接支 配方程式を解いて解析領域の応力・変形などを求め る方法であり，段階掘削や段階盛土，荷重載荷など の施工工程に沿った解析が可能である．本検討では， 解析プログラム FLAC (ver. 40)により解析を実施した.

\section{（1）解析条件およひ解析方法}

本解析で用いた有限要素メッシュと境界条件を図 -12に示す. 要素数は約 3500 メッシュとし，境界 条件は支持地盤下面を Y 方向固定, 盛土背面およひ 前面地盤をX 軸方向固定とした.

解析は，現地の施工手順を再現することとして， 幅 $25 \mathrm{~m}$ の切取り斜面上に, 一層 $(30 \mathrm{~cm}$ 厚さ)ごとに補強 盛土を構筑し, 各施工段階での安定解析を行った. 補強盛土構筑中のセメント改良アプローチブロック の物性は, 安定処理土が未固結であることを考慮し， 盛土材料の内部摩擦角 $\phi$ のみを用いた. 壁面工構築 後のセメント改良補強土橋台が完成した後の解析で は, 安定処理土の固結を考慮して, 室内配合試験の 結果からセメント改良土の粘着力 $\mathrm{c}=614 \mathrm{kN} / \mathrm{m}^{2}$ として 安定解析を行った. また, 地船材料については Mohr Coulomb の破壊基淮に準じた弾完全塑性体としてモデ ル化し, 補強材には線形のケーブル要素を用いてモ デル化した. 表一 4 , 表一 5 に各入力定数を示す. これら入力定数については，基本的には室内土質試 験, 補強材引張り試験等から定めたが, セメント改 良土の引張り強度については十分な試験が実施され ていなかったため, 水平載荷試験結果の逆解析によ り設定したものである. また, 補強材の降伏強度は, 引張強度の規格值（引張強度の特性值/0.8）を, 土衰 部の折り返しを考慮して 2 倍として入力した.

解析は，まず鉛直載荷による解析を実施した後， 水平載荷によるステップ解析を実施した. 鉛直荷重 は，現地載荷試験で実施した $1350 \mathrm{kN} /$ 全幅を再現する ため, 単位奥行き幅あたりの鉛直荷重 $122.73 \mathrm{kN} / \mathrm{m}$ を 桁座面両端に集中荷重として $61.36 \mathrm{kN} / \mathrm{m}$ ずつ載荷した. 水平載荷荷重は, 載荷試験の載荷位置と同じ位置で, 載 荷試験の最大荷重 $4000 \mathrm{kN} /$ 全幅と同值となるように $25 \mathrm{kN} / \mathrm{m}$ ずつ段階的に載荷し, 各荷重ステップで安定解析 を行った.

\section{(2) 解析結果}

図-13に水平載荷試験の測定結果と数值解析結果の 荷重〜水平変位の関係を, パラペット上端での変位とし て示す．また，図一 14に解析結果における荷重段階ご との水平変位分布を示す. 各図から, 水平荷重 $350 \mathrm{kN} / \mathrm{m}$ (4000kN/全幅) 時の変位は, 計測值 $15 \mathrm{~mm}$ 程度に対して, 解析值 $24 \mathrm{~mm}$ 程度であり, 解析値の方が約 1.5 倍大きい結 果であった。この原因としては, 実構造物は有限幅

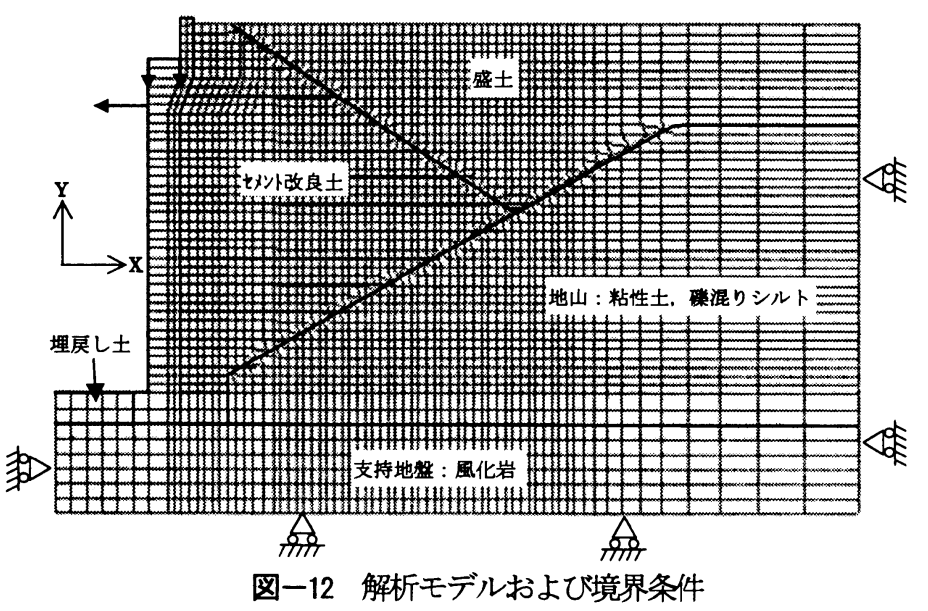

表-4 各入力定数

\begin{tabular}{|c|c|c|c|c|c|c|c|}
\hline 種類 & $\begin{array}{l}\text { 密度 } \\
\left(\mathrm{t} / \mathrm{m}^{3}\right)\end{array}$ & $\begin{array}{l}\text { ポア } \\
\text { 比 }\end{array}$ & $\begin{array}{l}\text { せん断岡门 } \\
\text { 性 }_{\text {mex }}(\mathrm{kPa})\end{array}$ & $\begin{array}{l}\text { 体積弾性 } \\
\text { 係数 } \mathrm{k}(\mathrm{kPa})\end{array}$ & $\begin{array}{l}\text { 粘着力 } \\
\mathrm{c}(\mathrm{kPa})\end{array}$ & $\begin{array}{c}\phi \\
\left({ }^{\circ}\right)\end{array}$ & $\begin{array}{c}\text { 引張強 } \\
\text { 度 }(\mathrm{kPa})\end{array}$ \\
\hline 盛土 & 2.7 & 0.25 & $4.00 \times 10^{5}$ & $6.67 \times 10^{4}$ & 44.7 & 55 & - \\
\hline 地山 & 1.5 & 0.3 & $4.73 \times 10^{3}$ & $1.03 \times 10^{4}$ & 1000 & 55 & - \\
\hline 支持地盤 & 1.9 & 0.3 & $1.85 \times 10^{4}$ & $4.00 \times 10^{4}$ & - & 50 & - \\
\hline 埋戻し土 & 1.8 & 0.3 & $4.81 \times 10^{3}$ & $1.04 \times 10^{4}$ & - & 20 & - \\
\hline セx性良士 & 2.7 & 0.25 & $2.50 \times 10^{6}$ & $4.16 \times 10^{6}$ & 614 & 61.8 & $3.5 \times 10^{6}$ \\
\hline ב多外 & 2.5 & 0.2 & $1.04 \times 10^{7}$ & $1.39 \times 10^{7}$ & - & - & - \\
\hline 土霊 & 2.0 & 0.3 & $2.12 \times 10^{4}$ & $4.58 \times 10^{4}$ & - & - & - \\
\hline
\end{tabular}

表一5 補強材の入力定数

\begin{tabular}{|c|c|c|}
\hline 項目 & $30 \mathrm{kN} / \mathrm{m}$ タイプ & $60 \mathrm{kN} / \mathrm{m}$ タイプ \\
\hline 密度 $\left(\mathrm{t} / \mathrm{m}^{3}\right)$ & $1.00 \times 10^{5}$ & $1.00 \times 10^{5}$ \\
\hline ポアル比 & 0.3 & 0.3 \\
\hline ヤグ係数 $\mathrm{E}(\mathrm{kPa})$ & $4.00 \times 10^{5}$ & $10.0 \times 10^{5}$ \\
\hline せん断剛性率 $\mathrm{G}(\mathrm{kPa})$ & $1.54 \times 10^{5}$ & $3.85 \times 10^{5}$ \\
\hline 厚さ (m) & 0.002 & 0.002 \\
\hline 断面積 (m') & 0.002 & 0.002 \\
\hline 降伏強度 $(\mathrm{kN} / \mathrm{m})$ & 76.4 & 147.0 \\
\hline 周長 (m) & 2.0 & 2.0 \\
\hline グラ外の剛性 (kPa) & $2.00 \times 10^{6}$ & $2.00 \times 10^{6}$ \\
\hline グラ外の剛性摩擦 $(\mathrm{kPa})$ & $1.00 \times 10^{3}$ & $1.00 \times 10^{3}$ \\
\hline 摩擦角( ) & 35 & 35 \\
\hline
\end{tabular}

(11. 3m) の 3 次元構造物であり, 橋台の側面部には線路 横断方向の補強材が配置されている. このことから, 解 析の 2 次元モデルよりも実際の構造物のほうが剛性が大 きく，その結果，解析のほうが変位が大きくなったもの と想定される.

図-15に設計地震動相当の水平荷重である $375 \mathrm{kN} / \mathrm{m}$ 時 のせん断ひずみのコンター図を示す．同図から，せん断 ひずみは第 6 層目の長尺補強材の端部位置付近の地表面 で大きな值を示しており, 水平載荷訊験のクラックの発 生位置とほほ一致している.

これらのことから，解析では水平変位量が若干大きな 值を示したが, 2 次元モデルであること, 背面地盤のひ ずみ分布から全体変形の傾向を再現していたことから， 解析モデルは概ね妥当であると判断した. 

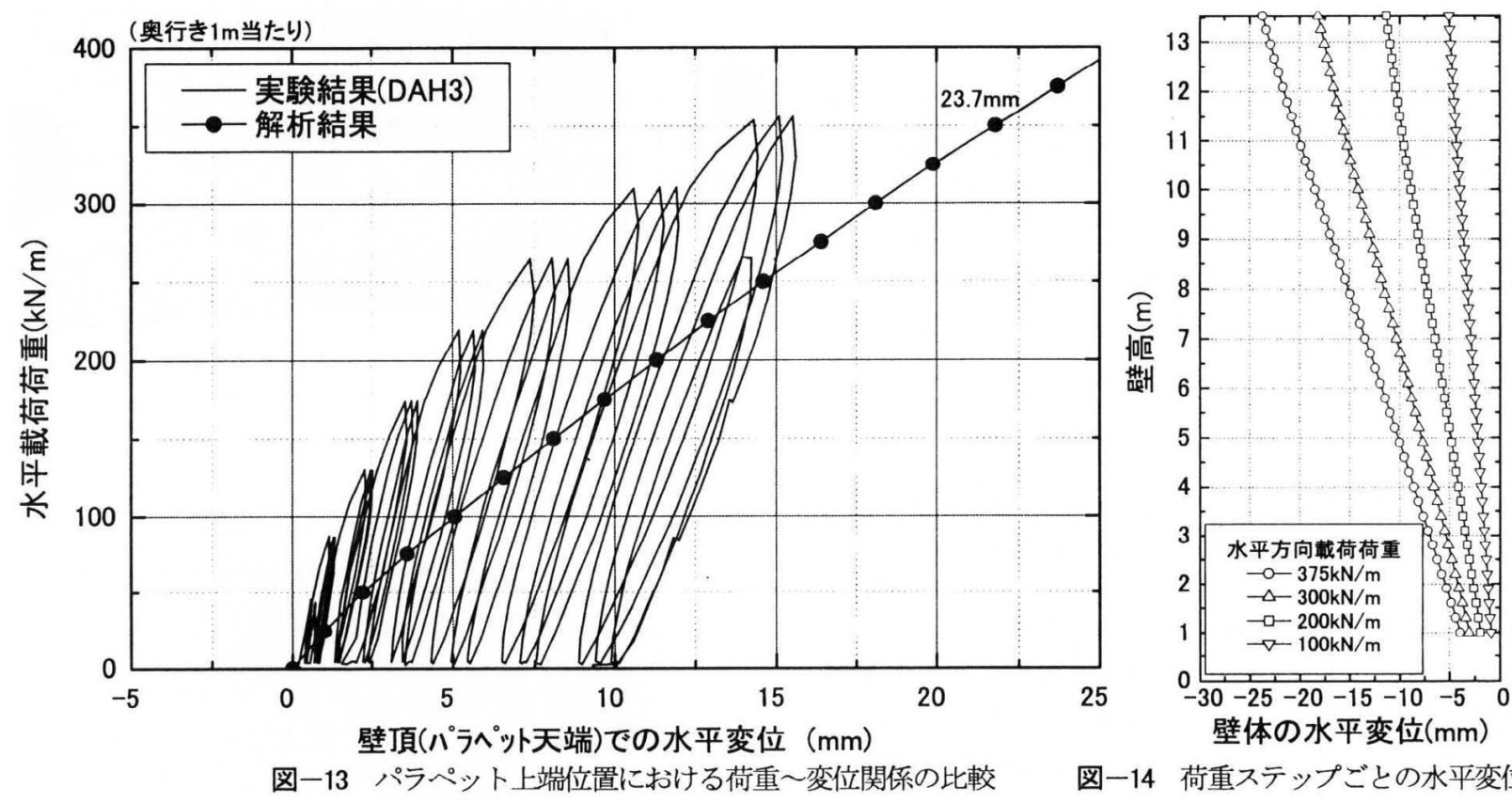

\section{5. 有限差分法による動的解析}

水平載荷試験の逆解析で決定した解析モデルを用いて 図ー 12 に示した有限要素メッシュ最下面にレベル2地 震の設計地震動を入力し, 地震時の動的変形挙動の検討 を行った.

\section{（1）動的解析における解析条件}

動的解析における境界条件は，自由境界とした。 また， 設計地震動は，支持地盤が $\mathrm{N} \geqq 50$ の砂礫地盤であること から，レベル2地震動を想定した耐震標準によるスペク トルII, G1地般用の設計地震動を入力した.

\section{（2）動的解析結果}

図ー16に基盤面を基に算定したパラペット天端と壁 面工中央部での相対変位時刻暦，図一 17 にパラペット 天端での最大応答加速度時の相対水平変位コンター図, 図一 18 にパラペット天端での最大応答加速度時の相対 変位ベクトル図を示す．図一16から，地震時のパラヘ ット天端の最大相対変位量は, 壁面工前面方向に $9.3 \mathrm{~cm}$ 示したが，残留変位量は1. $7 \mathrm{~cm}$ と小さかった。 また，地震 時の壁面工中央部の最大相対変位量は, 壁面工前面方向 に5. $3 \mathrm{~cm}$ を示したが, 残留変位量は $0.7 \mathrm{~cm}$ 非常に小さか った. 地震時の相対変位量がパラペット天端と壁面工中 央部で差が大きいことおよび図ー17の水平变位コンタ 一図から, 本橋台のレベル2地震時の変形モードは転倒 変形モードであると判断できる．また，パラペット天端 と壁面工中央部の残留変位量が小さいことから，レベル 2地震動下でもセメント改良補強土橋台は弾性的な挙動 を示したと考えられる.

図一 19に, パラペット天端での最大応答加速度時の 最大せん断ひずみコンター図を示す，パラペット天端が
最大応答加速度を示した時には，せん断ひずみはセメン 卜改良土と粘性土地盤の境界に沿って粘性土地盤内で発 達しているのがわかる。 また，セメント改良土内にはせ ん断ひずみはほとんど発生していないことから，高い耐 震性が示されたと判断できる.

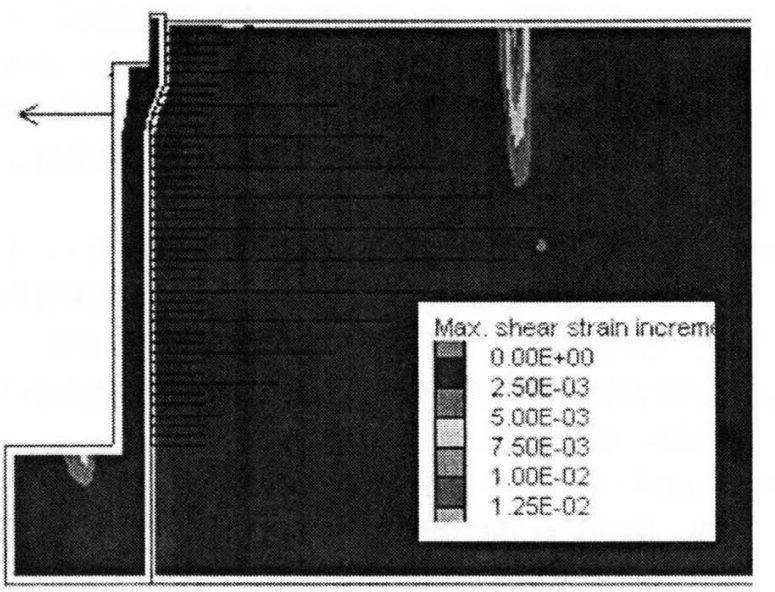

図一15 せん断ひずみ増分分布

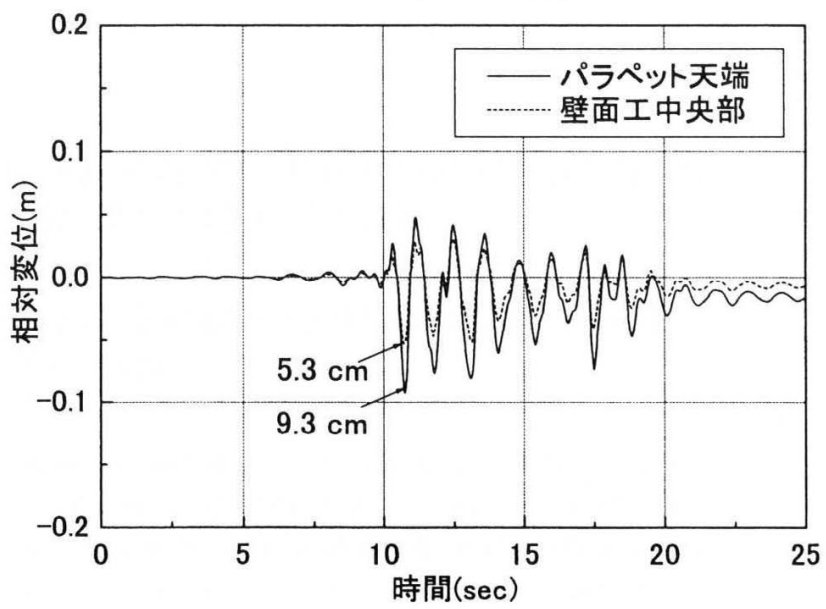

図-16 ペラペット天端と壁面工中部での相対変位時刻歴 


\section{6. おわりに}

現地水平載荷試験によるセメント改良補強土橋台の挙 動を設計的に再現し，本橋台の設計に用いた補強材ばね などの設計パラメータの検証を行うことを目的として, 静的非線形解析による逆解析を実施した. その結果, 当 初の設計における補強材ばね定数は, 逆解析の結果とほ ぼ一致した. また, 現地補強材引抜き試験の結果からも 概ね現実的なばね定数であると判断できた。このことか ら, 設計における補強材ばねの設定方法は, 妥当性が高 いと判断された.

さらに，背面地盤を含むセメント改良補強土橋台全体 系のレベル2地震動による動的な挙動を把握することを 目的として, 有限差分法による逆解析およひ動的解析を 実施した. その結果, 耐震標準に示されるスペクトルII 用設計地震動による本橋台の挙動は, 弾性的であり地震 後の残留変形も非常に小さいと判断された.これらのこ とから, セメント改良補強土橋台の高い耐震性が確認さ れたものと考えられる。

\section{参考文献}

1）矢崎澄雄・渡邊修・青木一二三・米澤豊司・舘山勝・龍岡文 夫・古関潤一：セメント改良補強土橋台の現地水平載荷訌験 （その1 : 実施概要），士木学会第58回年次学術講演会, 2003.

2）青木一二三・米澤豊司・加藤順・田村幸彦・舘山勝・龍岡文 夫・古関潤一: セメント改良補強土橋台の現地水平載荷試験 (その2: 変形モード), 土木学会第58回年次学術講演会, 2003.

3）青木一二三・米澤豊司・渡邊修・館山勝・龍岡文夫 : ジオテ キスタイルを用いたセメント改良補強土橋台の現地載荷試験 結果, 第18回ジオシンセティックスシンポジウム, 2003.

4）鉄道構造物等設計標準・同解説 耐震設計，運輸省鉄道局監 修鉄道総合技術研究所編, 1999.

5）内村太郎・龍岡文夫・青木一二三・米澤豊司・北野陽堂・舘 山勝・渡辺健治・田村幸彦・多尾孝之 : セメント改良粒調砕 石盛土中のジオグリッド補強材の引抜き試験, 第18回ジオシ ンセティックスシンポジウム, 2003.

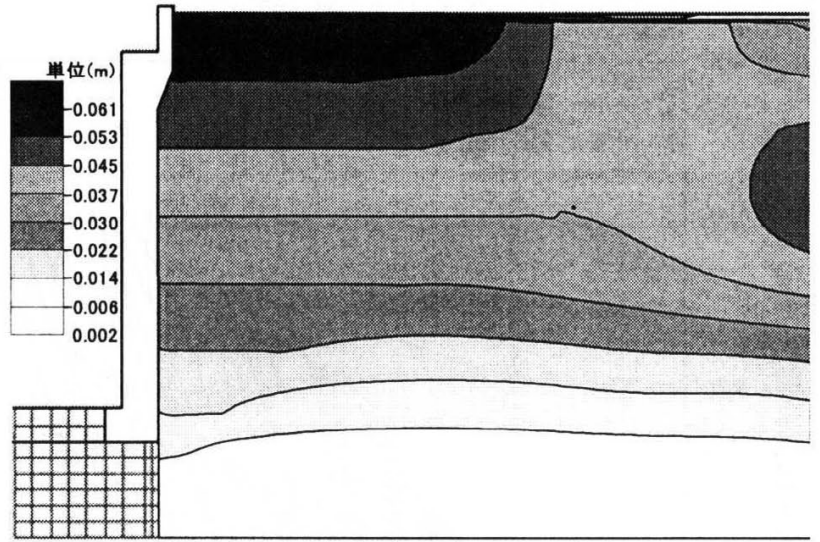

図-17 最大応答加速度時の絶対水平変位コンター図

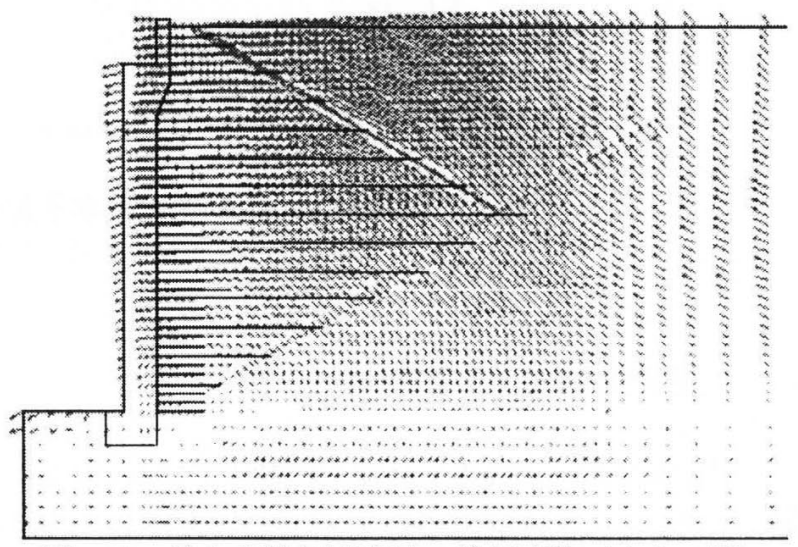

図一18 最大応答加速度時の絶対変位ベクトル図

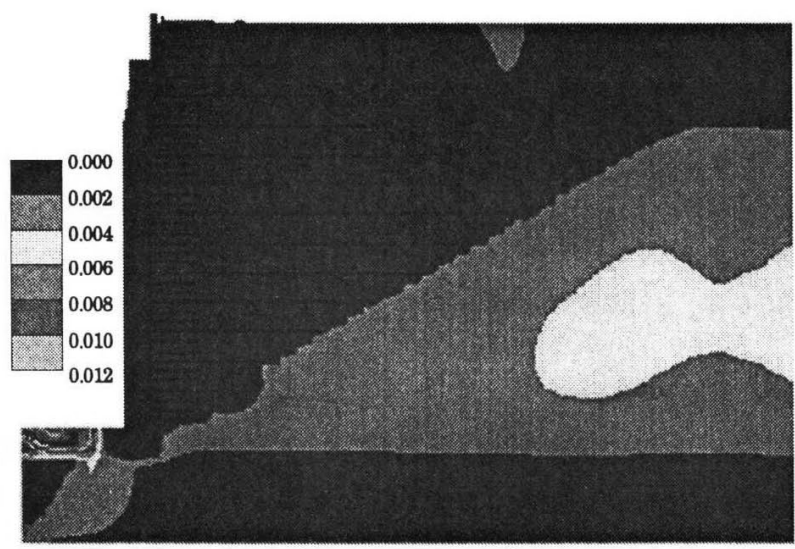

図一19 最大応答加速度時のせん断ひずみコンター図

\title{
FIELD TEST AND BACK ANALYSIS OF BRIDGE ABUTMENT WITH GEOGRID- REINFORCED CEMENT TREATED BACKFILL
}

\author{
Sumio YAZAKI, Hifumi AOKI, Toyoji YONEZAWA, Masahiro SHINODA and \\ Masaru TATEYAMA
}

\footnotetext{
The paper describes back analysis of the bridge abutment with geogrid-reinforced cement treated backfill subjected to vertical static load and horizontal cyclic load with static nonlinear analysis which is the conventional seismic design method. Input parameters for designing, such as spring coefficient of reinforcement, were examined by the above analysis. An dynamic analysis were also conducted with finite difference method based on the back analysis with the same method to expect the dynamic behavior of the bridge abutment subjected to strong seismic load.
} 